\title{
DEVELOPMENT ZOMBIE HUNTER BATTLEGROUND WITH FINITE STATE MACHINE DAN COLLISION DETECTION
}

\author{
Ita Arfyanti ${ }^{1}$, Salmon $^{2}$, Nursobah $^{3}$, Sugeng Suryani ${ }^{4}$ \\ 1,2,3,4 STMIK Widya Cipta Dharma \\ 19anita23@yahoo.com,.2salmon@wicida.ac.id, ${ }^{3}$ nursobah@wicida.ac.id, ${ }^{4}$ sugeng@gmail.com
}

\begin{abstract}
This research makes how to build a game with the theme of a knight / samurai who has a mission to hunt down all zombies who want to rule the world. A background in taking the theme of zombie games with the side scrolling game genre so that this game is easy to play. In this research game that is built using multimedia stages and also using the finite state machine and collision detection methods, where in multimedia developers there are 6 stages, namely: concept, design, material, preparation, test and distribution. The system development tools use a flowchart. And it is hoped that the game or game can entertain the players or make it a means of entertainment and can also be used as further research material for students and can be developed again for local game developers. The result of applying collision detection makes player and enemy characters more interactive and can attack each other.
\end{abstract}

Keywords - Game, Zombie Hunter, Finite State Machine, Collision Detection.

Abstrak- Penelitian ini membuat bagaimana membangun game 2D yang bertemakan tentang seorang ksatria/samurai yang memiliki misi untuk memburu seluruh zombie yang ingin menguasai dunia. Adapun latar belakang dalam mengambil tema game zombie dengan genre side scrolling game agar permainan ini mudah dimainkan dan menambah eksperimen pemain. Pada penelitian game yang dibangun menggunakan tahapan pengembang multimedia dan juga menggunakan metode finite state machine dan collision detection, dimana di dalam pengembang multimedia ada 6 (enam) tahapan yaitu: konsep, desain, pengumpulan materi, penyusunan, tes dan distribusi. Adapun alat bantu pengembangan sistemnya menggunakan Flowchart. Dan diharapkan game atau permainan tersebut dapat menghibur pemainnya atau menjadikan sebagai sarana hiburan. Hasil penerapan collision detection membuat karakter pemain dan musuh menjadi interaktif dan dapat saling menyerang.

Kata Kunci- Game, Zombie Hunter, Finite State Machine, Collision Detection.

\section{Pendahuluan}

Perkembangan Game saat ini mengalami perkembangan yang sangat pesat, tidak terkecuali di Indonesia. Game saat ini telah dimainkan oleh banyak orang dari usia muda sampai tua. Game jenisnya semakin bervariasi sejalan dengan perkembangan teknologi perangkat keras dan perangkat lunak $[1,2,3]$. Perkembangan game saat ini berkembang pesat, saat ini tidak hanya dimainkan di komputer [2], yang hanya bisa dimainkan dengan teman yang dikenal, tetapi saat ini sudah banyak game yang tersedia di dunia maya yang sering disebut dengan game on-line $[4,5]$ yang dimainkan oleh banyak orang dalam satu permainan walau jarak mereka saling berjauhan dan tidak saling mengenal.

Dengan kata lain, segala bentuk kegiatan yang memerlukan pemikiran, kelincahan intelektual dan pencapaian terhadap target tertentu dapat dikatakan sebagai game. Side Scrolling Game adalah salah satu genre game dengan sudut pandang kamera seolah - olah di samping karakter [3,6]dan mengikuti pergerakan pemain yang pada umumnya bergerak dari sisi kiri menuju sisi kanan layar untuk mencapai target atau lokasi yang di tentukan [6].
Alasan menerapkan side scrolling game pada game yang akan di bangun adalah karena game sejenis ini paling cocok untuk diterapkan pada umur 9 tahun ke atas, karena kontrol permainannya yang tidak terlalu rumit dalam memainkannya.

Salah satu metode yang sering digunakan dalam pembuatan game adalah Collision detection / metode tabrakan antar benda $[7,8,9,10]$. Collision detection merupakan Teknik deteksi tabrakan untuk mengetahui objek-objek apa saja yang bersentuhan dalam bidang koordinat tertentu [11,12]dan menggunakan Finite state machine (FSM) [13]sebagai sistem kontrol yang menggambarkan tingkah laku atau prinsip kerja sistem dengan menggunakan tiga hal berikut yaitu, State (Keadaan), Event (kejadian) dan Action (aksi).

Finite State Machine (FSM) atau sering disebut dengan Finite State Automata (FSA) [14], Mesin finite state, atau disingkat FSM [13] adalah model perhitungan berdasarkan mesin hipotetis yang dibuat dari satu atau lebih kedudukan $[13,14,15]$. Hanya satu kedudukan yang bisa aktif pada saat bersamaan, sehingga mesin harus berpindah dari kedudukan ke kedudukan lain agar bisa melakukan tindakan yang berbeda. FSM biasanya digunakan untuk mengatur dan 
merepresentasikan aliran eksekusi, yang berguna untuk menerapkan AI dalam permainan [16].

Berdasarkan latar belakang tersebut, maka diambil tema penelitian ini dengan judul Membangun Game "Zombie Hunter Battleground Dengan Menggunakan Metode Finite State Machine dan Collision detection. Dengan adanya FSM maka AI di dalam permainan ini dapat menjadi musuh yang interaktif bagi pemain dan collision detection akan membuat AI dapat menyerang dan melukai karakter pemain yang ada di dekatnya. Salah satu bentuk interaktif sebuah media adalah salah satunya menggunakan audio visual [17]. Kontribusi secara umum diharapkan game atau permainan tersebut dapat menghibur pemainnya atau menjadikan sebagai sarana hiburan dan juga dapat dijadikan bahan penelitian selanjutnya untuk mahasiswa serta dapat dikembangkan lagi kepada para pengembang game lokal

\section{METODE PENELITIAN}

Collision detection adalah proses pendeteksian tabrakan antara dua objek Sebenarnya dalam game sendiri tabrakan tidak hanya terjadi antara dua objek, tetapi dapat terjadi juga antara satu objek dengan banyak objek atau banyak objek dengan banyak objek [7]. Dapat dilihat pada gambar 1, dalam game membutuhkan collision detection yang akurat karena setelah menentukan terjadinya collision atau tidak kita harus menentukan apa yang terjadi pada objek yang ditabrak ataupun yang menabrak [18,19]. Collision detection ini juga berguna untuk menentukan posisi dari satu objek dengan objek yang lain sehingga tidak ada objek yang saling menembus. Sehingga game yang akan dibuat memiliki kesamaan dengan realita yang ada [20].

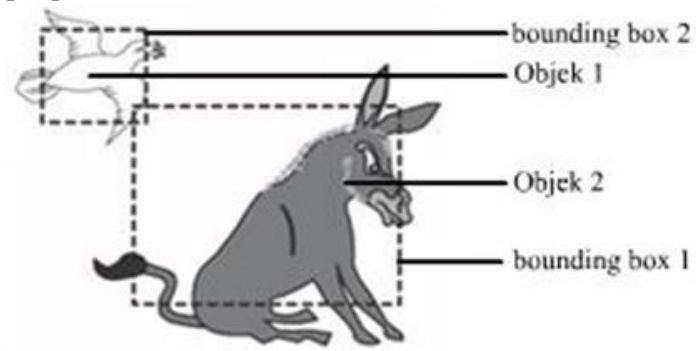

Gbr. 1 Contoh Reduce size bounding box Collision detection

Dapat dilihat pada gambar 2, metodologi yang dipakai adalah metode pengembangan multimedia yang terdiri dari enam tahap [21,22,23,24], yaitu concept (pengonsepan), design (mendesain), material collecting (pengumpulan materi), assembly (pembuatan), testing (pengujian), dan distribution (pendistribusian). Keenam tahap ini tidak dapat bertukar posisi . Meskipun begitu, tahap concept memang harus menjadi hal yang pertama kali dikerjakan [24]. Pengembangan multimedia agar dapat dimasukkan dalam pembelajaran harus melalui tahapan-tahapan yang terancang dengan baik dan runtut agar produk multimedia yang dihasilkan memiliki kualitas yang baik dan tepat digunakan dalam pembelajaran [25]

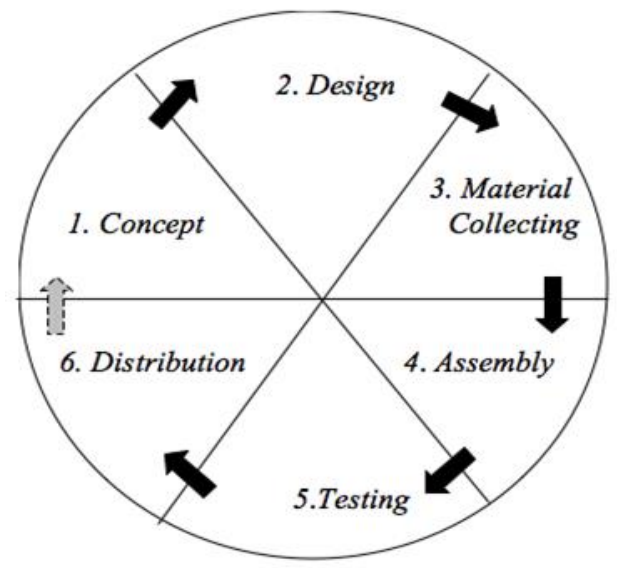

Gbr 2 Tahapan pengembangan Sistem

\section{HASIL DAN ANALISIS}

Berikut adalah rancangan dari Game Zombie Hunter Battleground :

\section{A. Flowchart Game Zombie Hunter Battleground}

Dapat dilihat pada gamabr 3, tampilan awal game Zombie Hunter Battleground menampilkan menu utama yang ada dalam game yang terdiri dari Play, Highscore, Help, About, Music, dan Exit Game. Jika memilih menu Play Game, maka akan menampilkan Select Level, kemudian misi yang harus diselesaikan pada Level 1. Jika Level 1 berhasil menyelesaikan misi maka akan dilanjutkan ke misi selanjutnya tetapi jika misi pada Level 1 tidak terpenuhi atau game over maka akan kembali ke menu awal. Kemudian terdapat menu Help yang berisi tentang informasi tombol apa saja yang digunakan pada layar screen smartphone untuk bermain game Zombie Hunter Battleground. Pada menu Credit berisi tentang Profile pembuat game Zombie Hunter Battleground. Pada menu Exit maka game akan berhenti dan keluar dari game.

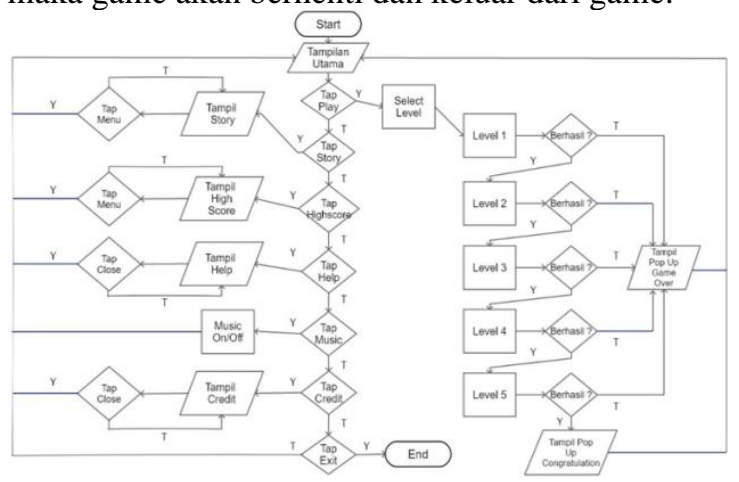

Gbr. 3 Flowchart Game Zombie Hunter Battleground 


\section{B. FSM pada Zombie 1}

FSM pada Zombie 1 dapat dilihat pada gambar 4. Alur FSM (finite state machine) pada karakter Zombie 1 memiliki sifat jika karakter Player mendekat pada jarak/range $<300$ pixel dari Zombie 1, maka Zombie 1 akan mengejar, dan jika Player mendekat pada jarak/range < 100 pixel maka Zombie akan menyerang Player, apabila player menjauh dari Zombie 1 dengan jarak/range > 300 pixel maka Zombie akan kembali Patrol pada tempat semula Zombie 1 berada, dan apabila player menyerang Zombie 1 hingga Health = 0 maka Zombie 1 akan mati, seperti yang terlihat pada Gambar 4.

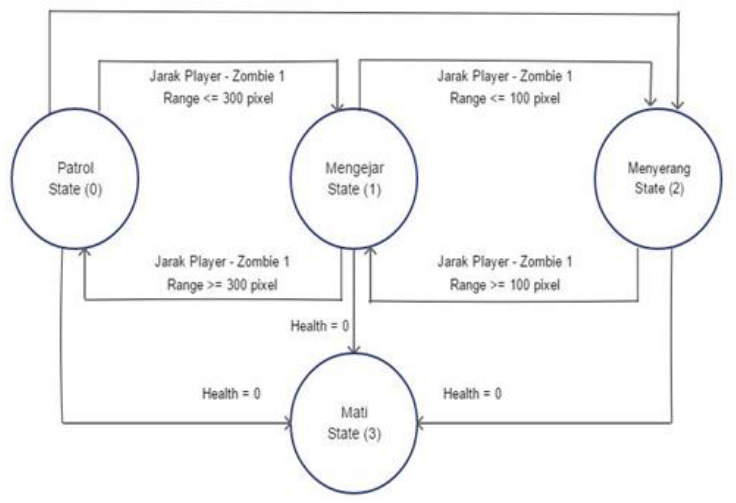

Gbr. 4 FSM pada Zombie 1

\section{FSM pada Zombie 2}

Alur FSM (finite state machine) pada karakter Zombie 2 memiliki sifat jika karakter Player mendekat pada jarak/range $<300$ pixel dari Zombie 2, maka Zombie 2 akan mengejar, dan jika Player mendekat pada jarak/range $<100$ pixel maka Zombie 2 akan menyerang Player, apabila player menjauh dari Zombie 2 dengan jarak/range > 300 pixel maka Zombie akan kembali Patrol pada tempat semula Zombie 2 berada dan apabila player menyerang Zombie 2 hingga Health $=0$ maka Zombie 2 akan mati, seperti yang terlihat pada Gambar 5.

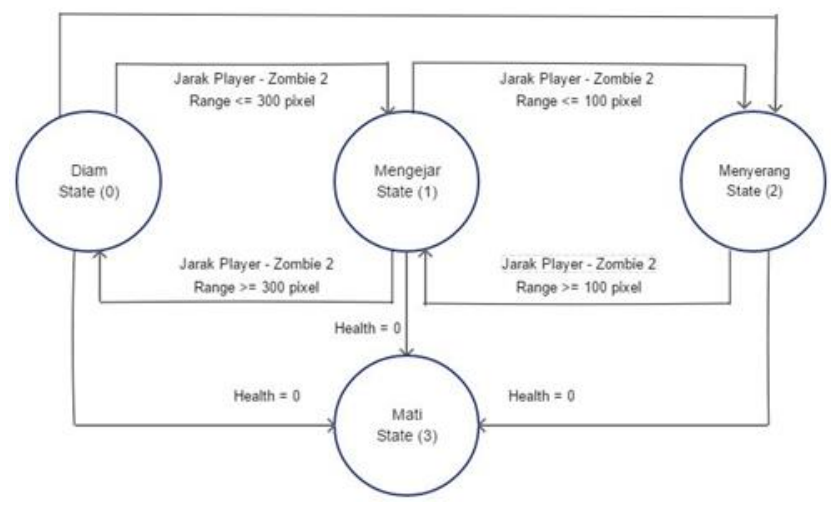

Gbr. 5 FSM pada Zombie 2
Alur FSM (finite state machine) pada karakter Boss memiliki sifat jika karakter Player mendekat pada jarak/range $<500$ pixel dari Boss, maka Boss akan mengejar, dan jika Player mendekat pada jarak/range $<100$ pixel maka Boss akan menyerang Player, apabila player menjauh dari Boss dengan jarak/range > 500 pixel maka Boss akan kembali Patrol pada tempat semula Boss berada dan apabila player menyerang Boss hingga Health $=0$ maka Boss akan mati, seperti yang terlihat pada Gambar 6.

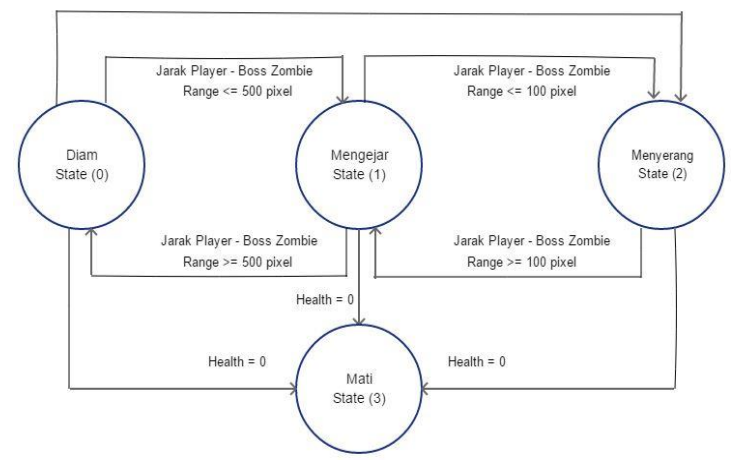

Gbr. 6 FSM pada Boss Zombie

\section{E. Flowchart serangan/attack}

Permainan game Zombie Hunter Battleground membutuhkan proses tubrukan antara satu objek dengan objek yang lain, Collision detection juga diimplementasikan pada game Zombie Hunter Battleground agar tidak tembus jika objek satu bertabrakan objek lain nya sehingga proses tubrukan akan terlihat nyata, Collision detection dimulai dengan mendeteksi posisi player dan posisi zombie sebagai enemy. Setelah objek player bergerak dan saling bertumbukan, persamaan logika akan mendeteksi apakah dua objek tersebut saling bertabrakan atau tidak. Jika tubrukan terjadi, maka collision detection akan terjadi dan melanjutkan alur pemrograman ke langkah berikutnya substract health. Begitu juga jika player bertumbukan dengan objek zombie lainnya maka metode collision detection akan dijalankan kembali. Pada alur yang terdapat pada gambar dibawah terdapat beberapa inisialisasi objek yang akan berjalan, selanjutnya ada proses pergerakan objek dan terlihat beberapa decision untuk memberikan cabang alur pada setiap kondisi, dimulai dari pergerakan player ketika melihat zombie maka dapat memberikan 2 opsi serangan shuriken untuk jarak jauh dan pedang untuk jarak dekat. Apabila player bertubrukan dengan zombie maka terjadi pengurangan pada health yang dimiliki player metode Collision detection terjadinya tubrukan antara 2 objek bisa di lihat pada Gambar 7 :

\section{FSM pada Boss Zombie}




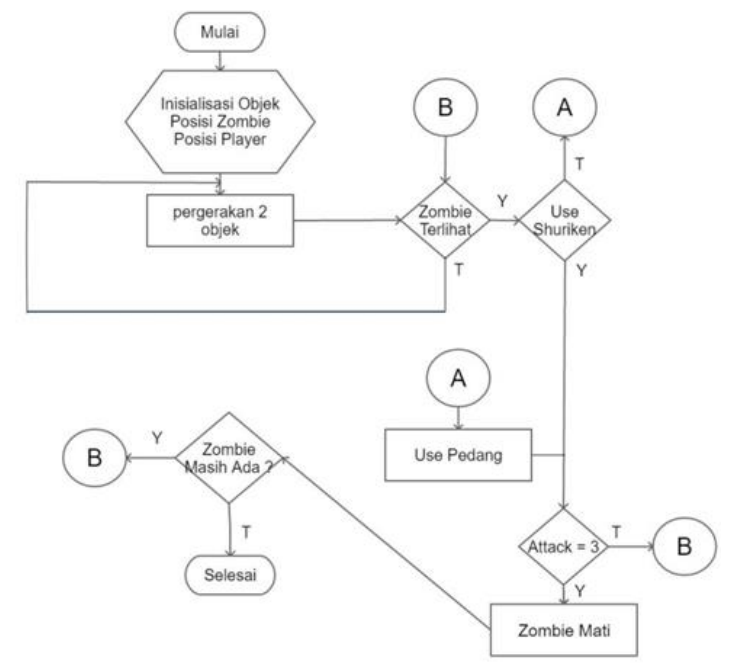

Gbr. 7 Flowchart Serangan/Attack

\section{F. Flowchart Collision detection Player terhadap Zombie}

Collision detection juga diimplementasikan pada game Zombie Hunter Battleground agar tidak tembus jika objek satu bertabrakan objek lain nya sehingga proses tubrukan akan terlihat nyata, Collision detection dimulai dengan mendeteksi posisi player dan posisi zombie sebagai enemy. Setelah objek player bergerak dan saling bertumbukan, persamaan logika akan mendeteksi apakah dua objek tersebut saling bertabrakan atau tidak. Jika tubrukan terjadi, maka collision detection akan terjadi dan melanjutkan alur pemrograman ke langkah berikutnya subtract health. Begitu juga jika player bertumbukan dengan objek zombie lainnya maka metode collision detection akan dijalankan kembali :

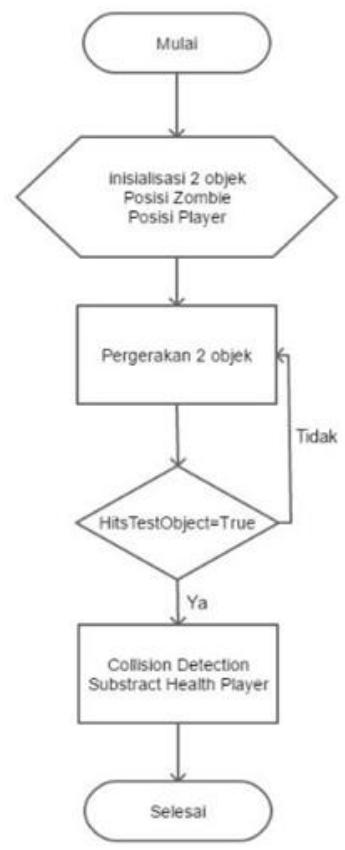

Gbr. 8 Flowchart Collision detection pada Player terhadap Zombie

\section{G. Antarmuka Game}

Dapat Menu utama merpakan tampilan utama dari game di saat permainan baru memasuki aplikasi. Pada gambar 9 menu utama terdapat judul dari game yaitu Zombie Hunter Battleground dan setiap tombol menu utama memiliki fungsi masing - masing. Ketika pemain mengklik/tap button Play maka akan menampilkan menu Level Select, dan di dalam Level Select maka player dapat memilih level/stage yang diinginkan. Saat pemain mengklik/tap button Story maka akan menampilkan cerita dari game tersebut, saat pemain mengklik/tap button Highscore maka akan menampilkan menu Top Score 10, jika pemain mengklik button help maka akan menampilkan menu help, jika pemain mengklik button exit maka pemain akan keluar dari game, jika pemain mengklik button i (info) maka akan menampilkan menu credits, di dalam menu utama ini terdapat music yang bisa dimatikan atau dinyalakan oleh pemain.

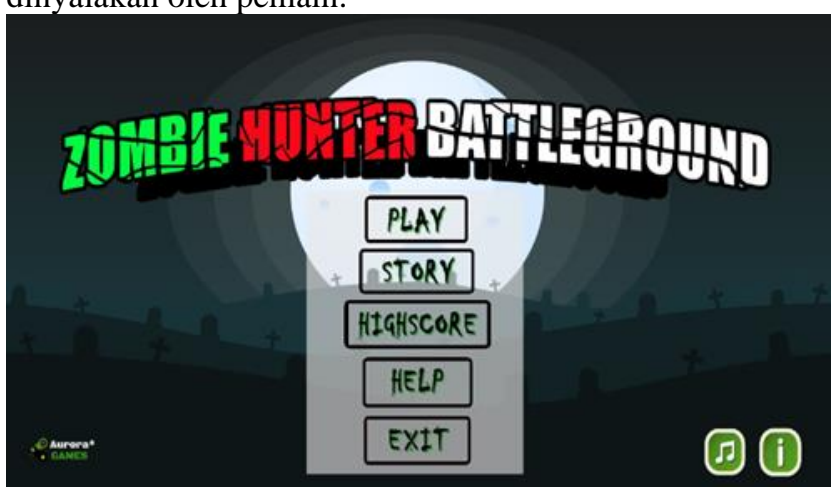

Gbr. 9 Tampilan Menu Utama

- Tampilan Select Level

Pada gambar 10 Menu select level ini terdapat button - button level yang bisa dipilih pemain. Pada menu ini terdapat lima tombol pilihan level yang ketika diklik akan masuk ke halaman level tersebut. Di dalamnya juga terdapat button menu untuk kembali ke menu utama.

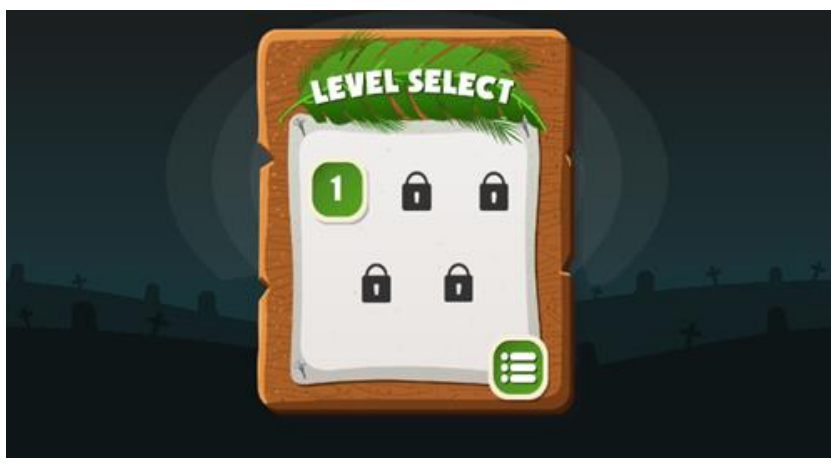

Gbr. 10 Select Level 


\section{- Tampilan Story}

Pada gambar 11. Menu Story ini menampilkan latar belakang cerita dari game Zombie Hunter Battleground, di dalamnya juga terdapat tombol menu untuk kembali ke menu utama.

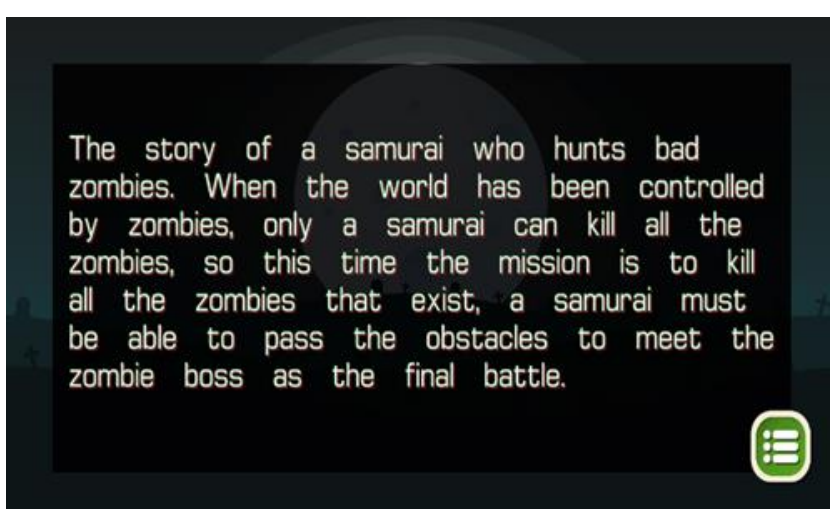

Gbr. 11 Tampilan Story

\section{- Tampilan HighScore}

Pada gambar 12 Menu Highscore ini menampilkan urutan score atau angka dari yang tertinggi dan yang terendah, di dalamnya juga terdapat tombol menu untuk kembali ke menu utama.

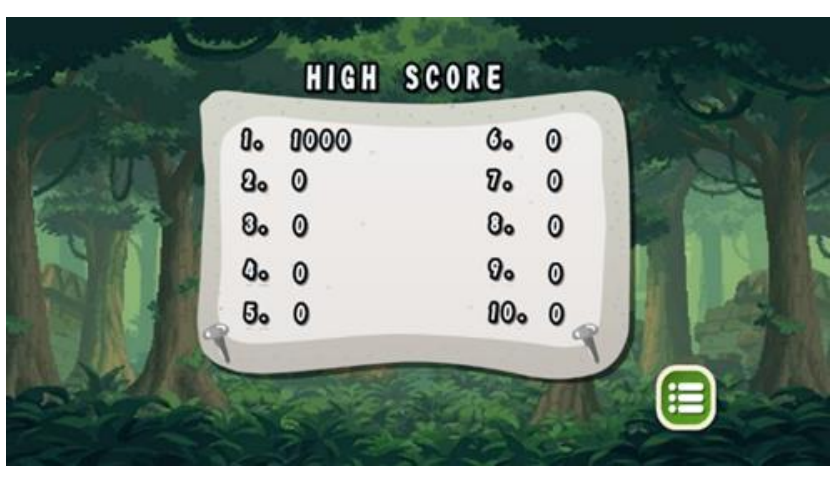

Gbr 12. Tampilan Highscore

- Tampilan Help

Pada gambar 13 Menu Help ini terdapat beberapa penjelasan tentang bagian - bagian yang terdapat di dalam game, di dalamnya terdapat tombol close jika ingin kembali menu.

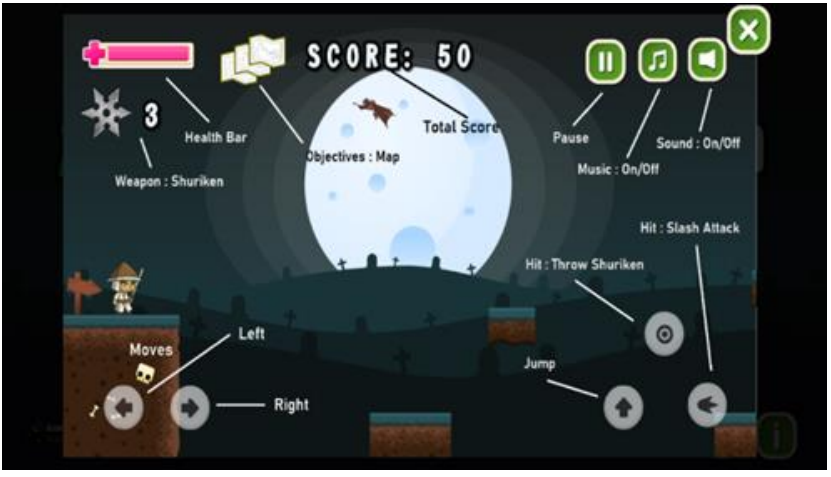

Gbr 13. Tampilan Help

- Tampilan Info/Credit

Pada gambar 14 Menu Info ini menampilkan menu credit saja dan menampilkan tombol close untuk kembali ke menu utama.

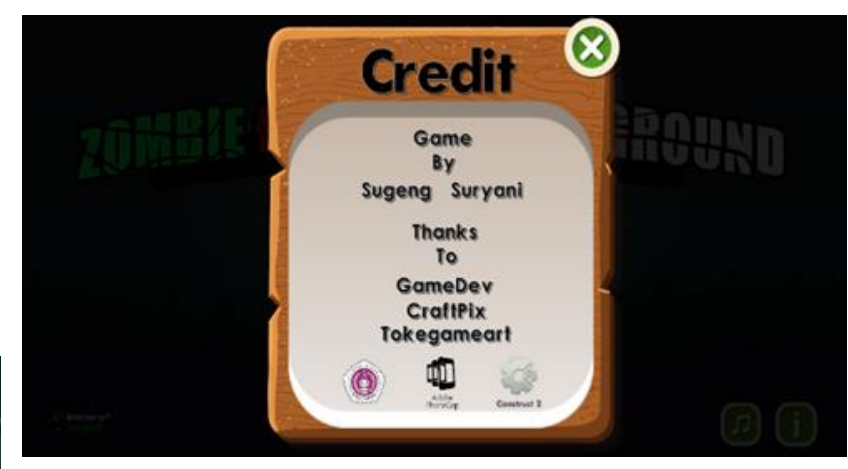

Gbr 14. Tampilan Info/Credit

- Tampilan Game

Pada gambar 15 Didalam ini terdapat sedikit penjelasan permainan. Dan jika pemain memilih button start game, akan masuk ke menu level select kemudian pemain memilih level yang diinginkan dengan mengklik level tersebut maka akan masuk ke level yang dipilih dan memulai permainan

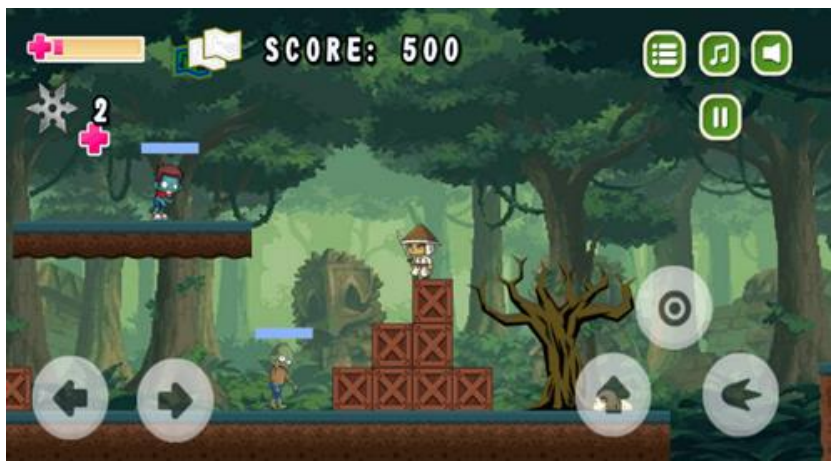

Gbr 15. Tampilan Game

- Tampilan Kalah

Pada gambar 16 Tampilan saat pemain gagal melewati rintangan atau pun mati maka akan menampilkan popup you lose. 


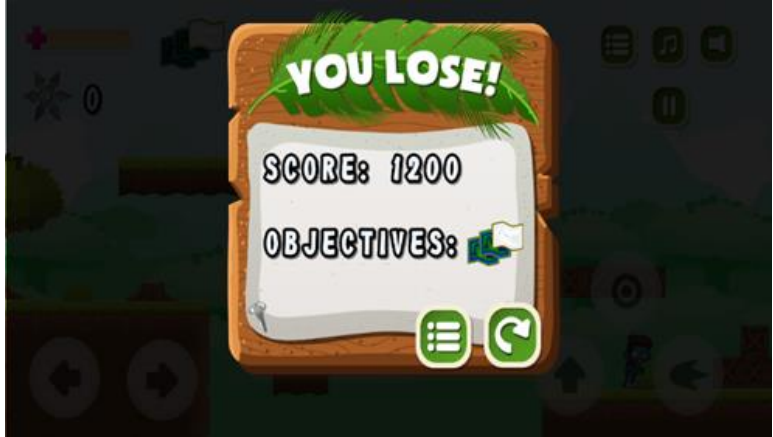

Gbr 16. Tampilan Kalah

- Tampilan Game Tamat

Pada gambar 17 Tampilan saat pemain berhasil melewati rintangan dan berhasil mengumpulkan semua objectives maka level selanjutnya akan terbuka dan ketika dilewati akan menampilkan popup you win.

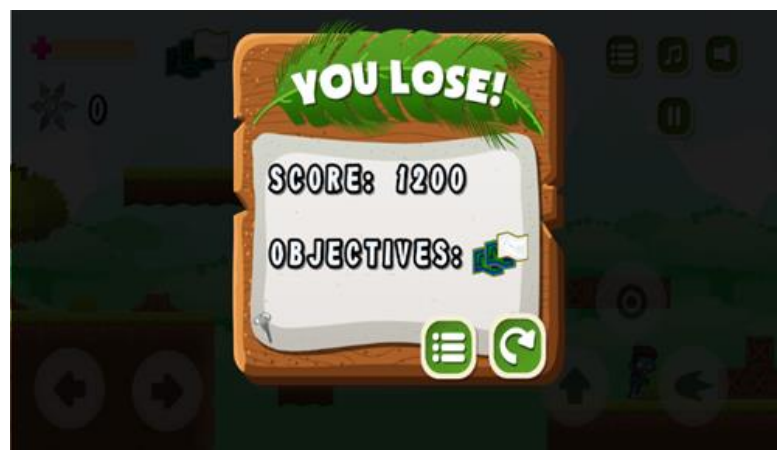

Gbr 17. Tampilan Game Tamat

\section{KESIMPULAN}

Pengembangan game Zombie Hunter Battleground melalui 6 tahap yaitu konsep, desain, pengumpulan bahan, assembly, pengujian dan pendistribusian. Game dibangun ber-grafis 2D dan ber--genre side scrolling game. Fungsi Finite State Machine pada game Zombie Hunter Battleground yaitu sebagai aksi Zombie pada saat ada kondisi tertentu, sedangkan Collision detection pada game Zombie Hunter Battleground yaitu untuk mendeteksi objek yang saling bertubrukan. Collision detection membuat karakter pemain dan musuh menjadi interaktif dan dapat saling menyerang. Jenis serangan yang digunakan dalam game ini hanya mempunyai serangan memukul dan melemparkan shuriken dapat dilakukan pemain atau pun karakter musuh.

\section{Referensi}

[1] David Silver et al., "Mastering the game of Go without human knowledge," Nature, vol. 550, no. 7676, pp. 354359,2017.[Online].

https://academic.microsoft.com/paper/2766447205

[2] Wan Jin, Lin Jian, Chen Yili, and Ling Cong, Game control method and device, 2017
[3] Diego Perez-Liebana et al., "General Video Game AI: A Multitrack Framework for Evaluating Agents, Games, and Content Generation Algorithms," IEEE Transactions on Games, vol. 11, no. 3, pp. 195-214, 2019. [Online]. https://academic.microsoft.com/paper/2963369679

[4] Seth Cooper et al., "Predicting protein structures with a multiplayer online game," Nature, vol. 466, no. 7307, pp. 756-760,2010.[Online].

https://academic.microsoft.com/paper/2073338313

[5] Bernardinus Harnadi, "An Investigation of the Adoption of Online Game Technologies in Indonesia," International Journal of Gaming and Computer-mediated Simulations,vol. 9, no. 1, pp. 1-27, 2017. [Online]. https://academic.microsoft.com/paper/2586771467.

[6] Wang Zesen, Game code checking method and game client side and system, 2016.

[7] Kevin J. DeMarco, Eric Squires, Michael Day, and Charles Pippin, "Simulating Collaborative Robots in a Massive Multi-agent Game Environment (SCRIMMAGE).," in DARS, 2019, pp. 283-297. [Online].

https://academic.microsoft.com/paper/2912003207

[8] Zeng Yan, Game-based collision detection method, game interaction method and live broadcast system, 2019

[9] Park Pyeong Geon, Device for data processing for responsive augmented reality card game by collision detection for virtual objects, 2019

[10] Robert Sajina and Tihomir Orehovacki, "User experience evaluation of 2D side-scrolling game developed using Overlap2D game editor and LibGDX game engine," in 2018 41st International Convention on Information and Communication Technology, Electronics and Microelectronics (MIPRO), 2018, pp. 1580-1585. [Online].

https://academic.microsoft.com/paper/2810656303.

[11] Ninghe M. Cai, Ahalya Mandana, Neha A. Reddy, and Netta Gurari, "Development of a Training Game to Coordinate Torques Produced Between Arms," in 2019 IEEE 16th International Conference on Rehabilitation Robotics (ICORR), vol. 2019, 2019, pp. 447-452. [Online].

https://academic.microsoft.com/paper/2964410980

[12] Cahill Jason Matthew, Merriam Jesse Dylan, Olafsson Torfi Frans, Schutz Timothy James, and Persson Michael Meincke, Shared Augmented Reality Game Within a Shared Coordinate Space, 2020.

[13] Erhan Bayraktar and Asaf Cohen, "Analysis of a Finite State Many Player Game Using Its Master Equation," Siam Journal on Control and Optimization, vol. 56, no. 5,pp.3538-3568,2018.[Online]. https://academic.microsoft.com/paper/2962739421

[14] Matthias Utesch, Andreas Hauer, Robert Heininger, and Helmut Krcmar, "The Finite State Trading Game: Developing a Serious Game to teach the Application of Finite State Machines in a Stock Trading Scenario," in REV2017 - 14th International Conference on Remote Engineering and Virtual Instrumentation, 2018, pp. 570582. [Online].

https://academic.microsoft.com/paper/2747223669

[15] Sharu Theresa Jose and Ankur A. Kulkarni, "On a Game Between a Delay-Constrained Communication System and a Finite State Jammer, " in 2018 IEEE Conference on Decision and Control (CDC), 2018, pp. 5063-5068. [Online].

https://academic.microsoft.com/paper/2913041701

[16] Vito Ren et al., "A technology platform for automatic high-level tennis game analysis," Computer Vision and Image Understanding, vol. 159, pp. 164-175, 2017. [Online].

https://academic. microsoft. com/paper/256782863 5

[17] Angraini W, Prihantoro C, Amin M, Yanuarti R. Penerapan Media Audio Visual Dalam Peningkatan Angka Pemberian Air Susu Ibu (Asi) Eksklusif Di Desa Kurotidur Kecamatan Argamakmur Kabupaten Bengkulu 
Utara. Jurnal Pengabdian Masyarakat Bumi Raflesia. 2019 May 5;2(1).

[18] Yu Manyou, Flight shooting game design of Android, 2018.

[19] Fengquan Zhang, Yujie Zhao, and Jiaojiao Guo, "A Virtual-Real Interaction Game Design Based on Motion Capture," in International Conference on Technologies for E-Learning and Digital Entertainment, 2017, pp. 3643.[Online].

https://academic.microsoft.com/paper/2763854071

[20] Chao Zhao, Mike Estep, and Feridoon Moinian, "Teaching Undergraduate Computer Graphics: Game Design and Implementation Utilizing the OpenGL Library and the Windows API," in 2017 International Conference on Computational Science and Computational Intelligence (CSCI), 2017. [Online]. https://academic.microsoft.com/paper/2904236296.

[21] Kathrin Gerling, Conor Linehan, and Regan Mandryk,., 2018,pp.465-484.[Online]. https://academic.microsoft.com/paper/2793464324

[22] A.M. Onencan, B. Enserink, and B.A. van de Walle, "Game Design Concept Report : Application of the WeShareIt Game Elements in Nzoia River Basin," 2018. [Online]. https://academic.microsoft.com/paper/2801305759

[23] Martin Kinitzki et al., "SERIOUS GAME DESIGN CONCEPT AND THE TECHNOLOGY ACCEPTANCE MODEL," in ICERI2019 Proceedings, 2019, pp. 40614070.[Online]. https://academic.microsoft.com/paper/2996594187

[24] Siiri Heikkinen, "The role of concept art in game design," 2018.[Online]. https://academic.microsoft.com/paper/3002465461

[25] Mario Garcia - Sanz, "Control Co - Design: An engineering game changer," Advanced Control for Applications: Engineering and Industrial Systems, vol. 1, no.1,2019.[Online].

https://academic.microsoft.com/paper/2971948046 